\title{
Entendendo muitos aspectos de mídias sociais Understanding many aspects of social media
}

\section{Anderson Marcusso}

Mestrando na Universidade Municipal de São Caetano do Sul (USCS) - São Caetano do Sul (SP), Brasil; Professor na FMU-FIAM-FAAM nos cursos de Publicidade e Propaganda, Rádio e TV e Tecnologia em Produção Publicitária - São Paulo (SP), Brasil. E-mail: fixo@terra.com.br

Para Entender as Mídias Sociais 21, publicado em 2012, tem Ana Bambrilla² como organizadora e autora, além de textos de outros 37 autores. Na obra, mídias sociais são relacionadas com conceitos, tecnologia, mercado de trabaIho, ambientes, formação e cidadania, além de textos que mostram "como proceder" em algumas situações.

Na primeira parte do livro, os autores procuram deixar claro o que significam alguns conceitos muito abordados na era das mídias sociais, como o engajamento tão desejado pelas empresas em suas ações virais nos sites de mídias sociais, as redes e as comunidades que precedem a própria Internet, o marketing colaborativo que acontece quando o movimento de muitos nas redes podem criar ações de marketing nas empresas, o behavioral marketing que envolve estudos de Antropologia por meio da Netnografia, a caracterização de memes e virais e suas diferenças, as mudanças na mentalidade do jornalismo na era da web $2.0 \mathrm{com}$ o envolvimento do leitor-produtor de conteúdo e, por fim, a Internet sob medida, que faz uso de recursos de "inteligência artificial" para apresentar os melhores resultados para as buscas dos internautas.

Em seguida, o capítulo \#TECH reúne vários assuntos ligados à tecnologia. Filipe Sperck traz o cenário do mercado de tablets, enquanto Renato Cruz faz observações sobre o Google Plus que ainda não "decolou" mesmo com a força do Google Inc. para impulsionar sua rede social. Michel Swartzman traz à tona a geolocalização para encontrar amigos pela rede social e saber onde cada um está em qualquer momento.

No capítulo \#JOBS, o mercado de trabalho de mídias sociais é atualizado pelos autores. O planejamento tradicional em agências de publicidade é importante também em mídia social segundo Manoel Fernandes. $O$ diagnóstico é fundamental para a mensuração de resultados e o

1 Bambrilla, Ana (Org.). Para Entender as Mídias Sociais 2. Salvador: Edições Vni, 2012. 278 p.

2 Ana Brambilla. Jornalista, mestre em Comunicação, organizadora do e-book "Para entender as mídias sociais 2". acompanhamento das ações virais nas redes sociais. Outra função interessante atualmente é a de hub: os antigos formadores de opinião para a mídia tradicional agora angariam usuários das redes sociais e podem ser pagos por isso. A monitoria envolve saber o que está sendo falado de marcas e empresas nas redes a fim de entrar nas conversações

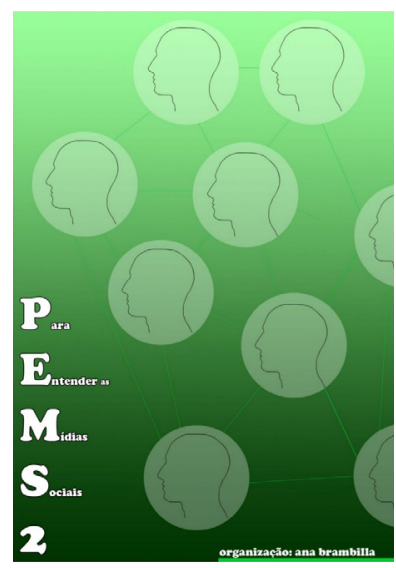
na tentativa de conduzir conflitos. Atender o consumidor pelas mídias sociais cria o conceito e a função do SAC 2.0, nem sempre bem utilizado pelas empresas. O blog corporativo envolve um profissional que alimenta o site da empresa, sendo, em muitos casos, mais eficiente do que o site tradicional de uma companhia. Por fim, o curador de conteúdo é quem seleciona, organiza e distribui notícias, posts e tweets para determinados públicos que passarão adiante a informação em suas redes.

O quarto capítulo, chamado \#COMOFAS, dá orientações de como agir em situações ligadas às redes sociais. A gestão de crises envolve posicionar a empresa perante situações disseminadas por usuários de rede e que preocupam a corporação. "Gestão de equipes" trata dos funcionários de empresas como principais faladores sobre a empresa e da política de restrição das redes na empresa. "PR digital" atualiza Relações Públicas para a interface digital das redes e suas diversas possibilidades, e alternativas frente ao mix de comunicação tradicional. O conjunto de técnicas de como escrever para Internet, especialmente para a era do Twitter, é caracterizado como Webwritting. As orientações passo a passo para empresas descobrirem as redes e entender o que falam dela são vistas em "Monitoria corporativa". "Integração on-offline", por sua vez, mostra que ambos os ambientes são importantes e complementares na era das redes sociais.

\#AMBIENTES é um capítulo que procura mostrar alguns ambientes envolvidos com mídias sociais. Varejo trata de atendimento ao cliente e suas reclamações, e "Intranets e capital intelectual" explica a importância do estímulo do 


\section{Entendendo muitos aspectos de mídias sociais}

engajamento pela empresa. Empresas de capital aberto agora estão presentes também nas redes, como visto em "Governança corporativa"' "Literatura" fala do mercado editorial nas redes e "Arte" trata basicamente de infográficos e I-livros na rede.

O capítulo \#FORMAÇÃO está ligado ao aprendizado. O conteúdo apresentado em "E-Learning" lida com os ambientes virtuais de aprendizado, "Formação do profissional" aborda os perfis público e privado de profissionais nas redes, ao passo que "Ecologia cognitiva" é a parte que aborda as redes sociais no processo de informação pública em tragédias, desastres e conflitos sociais. Os aspectos do ensino relacionado às ferramentas como Orkut e Twitter são desenvolvidos no texto "Pedagogia".

A última parte, \#CIDADANIA, concentra os assuntos que envolvem cidadania e participação social. Esse capítulo aborda a nova classe $\mathrm{C}$ brasileira agora conectada, a mobilização dos principais movimentos de reivindicação e protesto mundiais (especialmente em 2011), o bloqueio do acesso às redes que se faz em empresas e escolas para os usuários que são o principal público propagador da imagem da empresa, as cidades que já são digitais por conta da participação governamental no processo, além de globalização, identidade e democracia no ambiente das redes. 